\title{
Renewable power interface based rural telecom
}

\author{
W. Margaret Amutha, H. Caleb Andrew, A. Debie Shajie, J. Praveen Immanuel Paulraj \\ Department of EMT, Karunya Institute of Technology and Sciences, India
}

\begin{tabular}{l}
\hline \hline Article Info \\
\hline Article history: \\
Received Sep 6, 2018 \\
Revised Nov 19, 2018 \\
Accepted Feb 15, 2019 \\
\hline
\end{tabular}

\section{Keywords:}

Cuk-sepic interface MATLAB/SIMULINK MPPT

Renewable power interface

Solar-wind hybrid system

\begin{abstract}
To power remote area telecom where grid supplied electricity is unreliable, an alternative exists in the form of renewable energy sources. These sources mainly rely on the weather condition of a particular area for their source of power. To overcome such problem, hybridization of energy sources are prefered. Hybridization of solar-wind systems use a separate converter for each source thus leading to a complex, bulky and less efficient system. This paper presents a single renewable power interface which allows solar and wind sources to supply the load separately or simultaneously depending on the availability of the energy sources. It uses cuk and sepic converter topologies to form cuk-seic interfece. These systems also use battery backup to store excess energy and to make best use of their operating characteristics. Performance comparison between a cuk-sepic renewable power interface with and without MPPT using MATLAB/SIMULINK is presented. A detailed componentwise analysis is also done to calculate best efficient interface. It is found that the cuk-sepic interface with MPPT is efficient. A lab level model for cuk-sepic interface is developed and tested. The experimental results proved the effective operation of a single renewable power cuk-sepic interface with MPPT.
\end{abstract}

Copyright (C) 2019 Institute of Advanced Engineering and Science. All rights reserved.

\section{Corresponding Author:}

\section{W. Margaret Amutha}

Department of Electronics and Media Technology,

Karunya Institute of Technology and Sciences,

Karunya nagar, Coimbatore, Tamilnadu, India.

Email: margaret@karunya.edu

\section{INTRODUCTION}

India is the world's second largest telecom subscriber base of 700 million and it may come to 800 million in coming years. $24 \times 7$ power supplies are required to operate the telecom equipment. However due to lack of stable grid power in rural or remote areas, telecom operators face a big challenge. So, telecom equipment are running on diesel generator (DG) or batteries during demand period which leads to a threat of global warming and $\mathrm{CO} 2$ emissions. This increases the focus on powering telecom towers through renewable energy sources like solar, wind, tidal etc. Yousef Mohmoud et al. [1], and Pradhan et al. [2], have discussed the photovoltaic modelling and simulation of solar arrays. Nath [3] and Bharani Kumar [4] have reported the modelling and simulation of wind turbine. According to both the authors, the components in solar and wind systems are modular which makes the design and installation very feasible and practical.

However the difficulties like intermittency and instability etc., associated with the renewable energy sources, combined utilization of renewable sources with proper battery backup are preferred. Ersan Kabalci [5], Xiong Liu et al. [6], Salameh et al. [7], and Billington [8] suggested a viable independent power industry that serves the public interest by providing cost effective power supply through the environment responsible and efficient development of the available solar/wind/battery energy sources. When a source is unavailable or insufficient in meeting the load demands, the other energy source can compensate for the difference. When a source produces excess energy than load demand, it can be stored in battery. When neither the wind nor the solar systems are producing, power can be supplied by the batteries. So, to 
achieve, reliable, environmentally friendly and uninterrupted power supply, two or more number of renewable energy systems are integrated.

Providing a good match between these two energy sources are also a complicated task. Hence DCDC converters are used whenever change of dc power from one voltage level to another voltage level is required. As reported by Neng Zhang et al., Akar et al., Shahar Banu et al., Narendra Nath et al., [9-12] the interface systems for renewable energy sources were constructed using the topology which consists of multiple energy inputs connected to a respective DC-DC converter with its own controller and storage element. Each DC-DC converter is connected to a common dc link. The common dc link is where the energy from each input is combined and then distributed to the loads through another DC-DC converter for each load. In a system of this nature [13-15], each DC-DC converter communicates with each other in order to control the power transferred from each input to its respective output. With this type of topology if one were to add multiple input modules, the overall system would become too large for its particular application where size and weight are an issue.

According to [16- 20] Jafar Marjani et al., Suresh et al., Maria Bella Ferrara et.al., Sajib et al., and Jayalakshmi et al., a single multi-port DC-DC converter topology can be an alternative to renewable energy source interfacing. It is more advantageous to use integrated converters with multiple ports instead of several individual converters as it results in less component count, lower cost. It can deliver power to the load either simultaneously or individually based on the battery utilization. So this paper proposes a single cuk-sepic integrated converter based hybrid solar-wind renewable energy sources powering rural telecom. As reported in the literature [21], the use of a maximum power point tracking technique (MPPT) algorithm is also necessary to extract as much power as possible from the solar and wind when its irradiation and speed changes. Existing literarure [22] also dealt about PI controller, MPPT algorithm for multiple renewable energy sources with separate DC-DC converters. This paper proposes a MPPT algorithm for hybrid solarwind system with a single cuk-sepic integrated DC-DC converter. Most common method to achieve MPPT in solar and wind systems is perturb \& observe $(\mathrm{P} \& \mathrm{O})$ algorithm.In this paper, the perturbation and observe $(\mathrm{P} \& \mathrm{O})$ method is used for both the solar and wind energy sources.

This paper is organized as follows. The first section is a short overview of the literature. In the second section block diagram, system description and simulation results of single cuk-sepic interface based solar-wind hybrid system powering rural telecom with MPPT and without MPPT are presented. Third section deals about the simulation results and efficiency comparison. Fourth section contains the hardware description and results. Finally, the findings of the investigations are highlighted in the conclusion.

\section{BLOCK DIAGRAM}

The block diagram of the cuk-sepic interface without and with MPPT for powering rural telecom is shown in Figure 1. It contains two generating power plants, a solar system and a wind system. AC power obtained from wind source is rectified into dc power using controlled rectifier circuit and connected to the interface circuit. Solar power is directly connected to the interface circuit. Both the solar and wind systems are incorporated together using a single renewable power interface circuit. The load is supplied mainly from wind system during winter time whereas solar system is supplied during summer period. The output of cuksepic interface is used for charging the battery that supplements power to the telecom load.
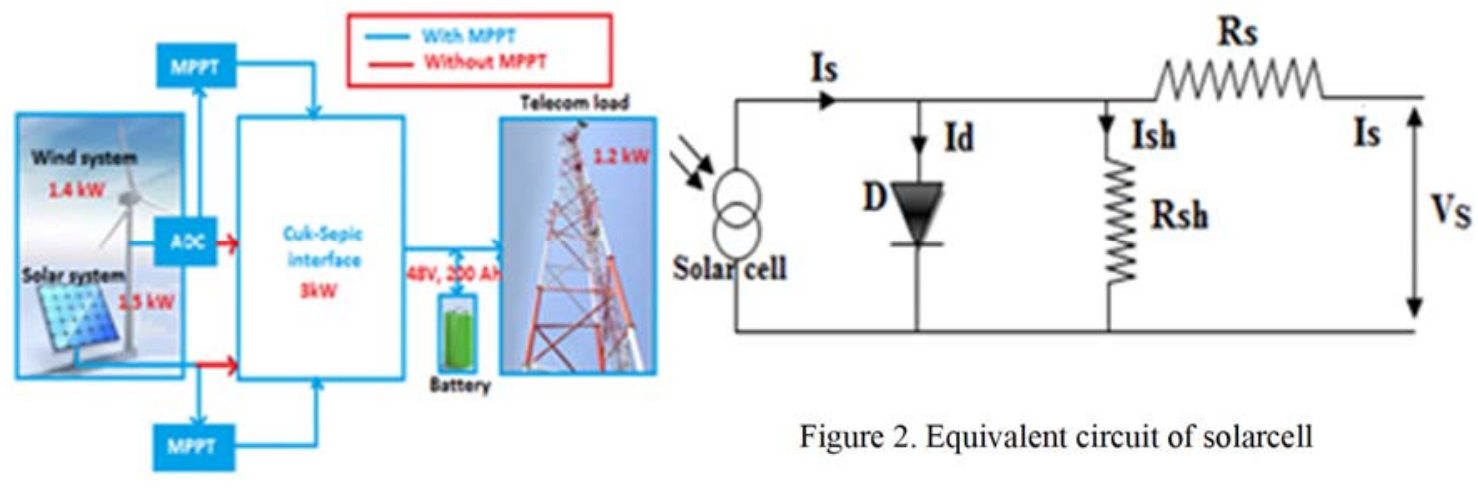

Figure 2. Equivalent circuit of solarcell

Figure 1. Block diagram of cuk-sepic interface(without/with)MPPT 


\subsection{System description}

\subsubsection{Solar system}

Solar cell is the basic element of a solar photovoltaic system. A solar cell is a semiconductor diode whose p-n junction is open to the light. When sunlight strikes the solar cell junction, free electrons and holes are generated and current is delivered to the load when it is short circuited. A grouping of solar cells forms a solar panel. To obtain large output voltage solar panels are formed by connecting solar cells in series and to achieve large output current cells are connected in parallel. Figure 2 shows the equivalent circuit of a solar cell. The basic equation that describes the I-V characteristics of the solar cell is given as,

$$
\mathrm{I}=\mathrm{I}_{\mathrm{s}}-\mathrm{I}_{\mathrm{d}}\left\lceil\exp \left(\frac{\mathrm{q} * \mathrm{~V}}{\mathrm{a} * \mathrm{k} * \mathrm{~T}}\right)-1\right\rceil
$$

Where

$\mathrm{I}_{\mathrm{s}}$ : Incident sunlight current

$\mathrm{I}_{\mathrm{d}} \quad$ : Shockley diode equation

q :Electron charge $(1.602 \times 10-19 \mathrm{C})$

$\mathrm{k}$ : Boltzman constant $(1.3806 \times 10-23 \mathrm{~J} / \mathrm{K})$

$\mathrm{T}:$ Temperature of the $\mathrm{p}-\mathrm{n}$ junction

a : Diode ideality constant

To observe solar characteristics some additional parameters should be included in (1). Hence the equation is represented as,

$$
I=I_{S}-I_{o}\left\lceil\exp \left(\frac{V+\left(R_{s} * I\right)}{a * V_{t}}\right)-1\right\rceil-\left\lceil\left(\frac{V+\left(R_{S} * I\right)}{R_{P}}\right)\right\rceil
$$

Where

$\mathrm{V}_{\mathrm{t}} \quad$ : Thermal voltage

$\mathrm{R}_{\mathrm{s}} \& \mathrm{R}_{\mathrm{p}}$ : Equivalent series and parallel resistances

The incident light current of solar cell depends on solar irradiation. It can be expressed as,

$$
\mathrm{I}_{\mathrm{s}}=\left(\left(\mathrm{I}_{\mathrm{s}, \mathrm{n}}+\mathrm{K} * \Delta \mathrm{I}\right) * \mathrm{G}\right) / \mathrm{G}_{\mathrm{n}}
$$

Where

$\mathrm{I}_{\mathrm{s}, \mathrm{n}} \quad$ : Incident light current at nominal conditions $(25 \mathrm{oC}$ and $1000 \mathrm{~W} / \mathrm{m} 2)$

$\Delta \mathrm{T}-\mathrm{T}-\mathrm{T}_{\mathrm{n}}:$ (difference between actual and nominal temperature)

$\mathrm{G}$ and $\mathrm{G}_{\mathrm{n}}$ : actual and nominal irradiation respectively

$$
I_{o}=I_{o}\left(\frac{T_{n}}{T}\right) \exp \left\lfloor\frac{q * E_{g}}{a * k}\left(\frac{1}{T_{n}}-\frac{1}{T}\right)\right\rfloor
$$

Where

$\mathrm{E}_{\mathrm{g}}$ : band gap energy of the semiconductor

$I_{o n}$ : Nominal saturation current

Based on the above mathematical equations Simulink modelling of solar module is done and Figure 3 shows the IV characteristics of solar system. From Figure 3, it is clear that the open circuit coltage is $80 \mathrm{~V}$ and the short circuit current is 19A. So, the total solar power considered for the analysis is $1.5 \mathrm{~kW}$. Figure 4 gives solar current and solar voltage and solar power of the same.

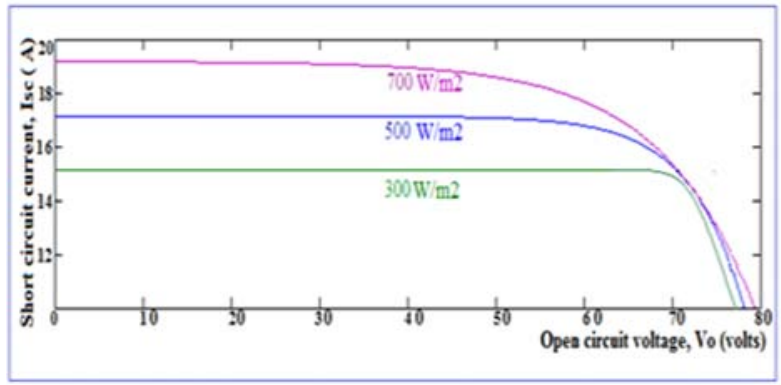

Figure 3. IV characteristics of the solar system 


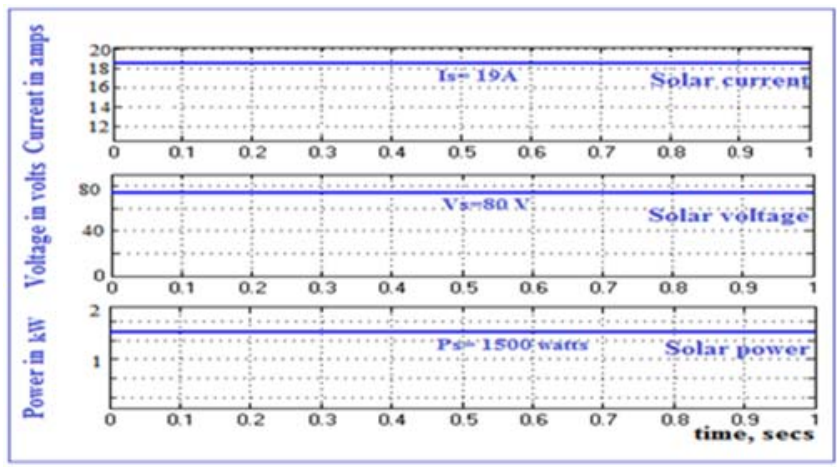

Figure 4. Solar current, voltage and power

\subsubsection{Wind system}

Wind system is one of the promising, environment friendly, abundant available sources of an alternative energy. The wind system can consist of a wind turbine coupled with a permanent magnet synchronous generator (PMSG) and a rectifier circuit or a wind turbine coupled to a dc machine to get dc voltage. Wind turbine converts the kinetic energy of wind in to mechanical energy. The magnitude of this converted mechanical energy depends on the air density and the wind velocity. The wind power $\left(\mathrm{P}_{\mathrm{m}}\right)$ that is developed by the turbine is given by the equation,

$$
\mathrm{P}_{\mathrm{m}}=\frac{1}{2} * \mathrm{C}_{\mathrm{p}} *(\lambda, \beta) * \rho * \mathrm{~A} * \mathrm{w}^{3}
$$

Where

$\mathrm{C}_{\mathrm{p}} \quad$ : Performance coefficient of turbine

$\rho \quad$ : Air density $(\mathrm{kg} / \mathrm{m} 3)$

A : Area of turbine blades $(\mathrm{m} 3)$

W : Wind velocity $(\mathrm{m} / \mathrm{sec})$

$\lambda \quad:$ Tip speed ratio of the rotor blade tip speed to wind speed

$\beta \quad$ : Blade pitch angle (deg)

The coefficient $\mathrm{Cp}$ is the fraction of kinetic energy which is converted by wind turbine into mechanical energy. It is related to the tip speed ratio $(\lambda)$. Wind turbine output torque $(\mathrm{Tm})$ can be calculated using equation,

$$
\mathrm{T}_{\mathrm{m}}=\frac{1}{2} * \mathrm{C}_{\mathrm{p}} * \mathrm{~A} * \rho * \frac{w}{\lambda}
$$

Using the above equations a Simulink model is implemented and Figures 5 and 6 shows generator speed vs mechanical output power (pu) characteristics of the wind system and wind voltage, current, power obtained from simulation.

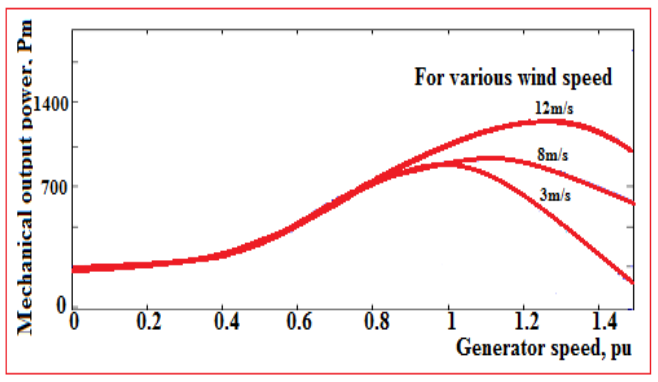

Figure 5. Generator speed Vs Mechanical output power

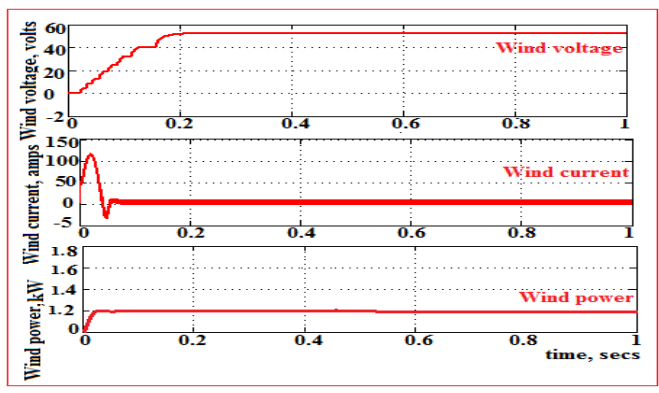

Figure 6. Wind voltage,current and power 


\subsubsection{P \&O algorithm}

Modeling of perturb and observe ( $\mathrm{P} \& \mathrm{O})$ maximum power point algorithm is discussed here. Renewable energy sources are a form of unstable energy. So, it is necessary to track the maximum power point (MPP) continuously in order to maximize the power output from the renewable energy sources. There are several MPP tracking methods in the literature, such as Perturb and Observation (P \&O) algorithm, Incremental Conductance (INC) algorithm, neural network control, fuzzy logic control and digital signal processor based implementation. This work uses Perturb and Observe ( $\mathrm{P}$ and $\mathrm{O})$ algorithm are due to its least cost implementation.

In $\mathrm{P} \& \mathrm{O}$ algorithm, a small perturbation is introduced in every iteration to alter the duty cycle in order to force the operating point to move near the maximum power. This algorithm compares the power of the previous step with the power of the new step to determine the next perturbation. If the power increases due to the added perturbation then the perturbation will remain in the same direction. If power decreases due to the added perturbation then the perturbation reverses the direction. When the steady-state is reached, the algorithm oscillates around the peak point. In order to maintain small variation, the perturbation size is kept very small. The working of $\mathrm{P} \& \mathrm{O}$ algorithm is illustrated in the Figure 6(a). Comparison of solar output power with and without MPPT, wind output power with and without MPPT is shown in Figure 6(b) and 6(c) respectively. From the figures, it is explicit that the cuk-sepic converter with MPPT produces more renewable power.

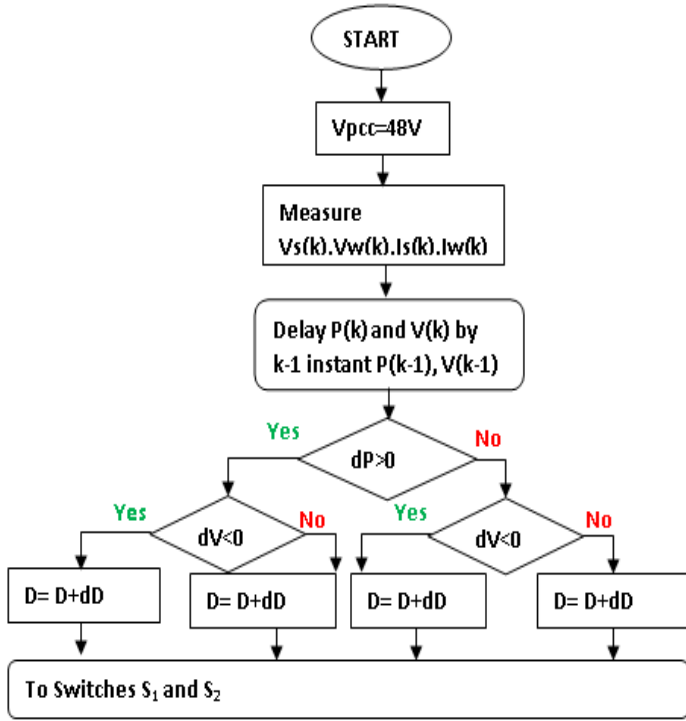

(a)

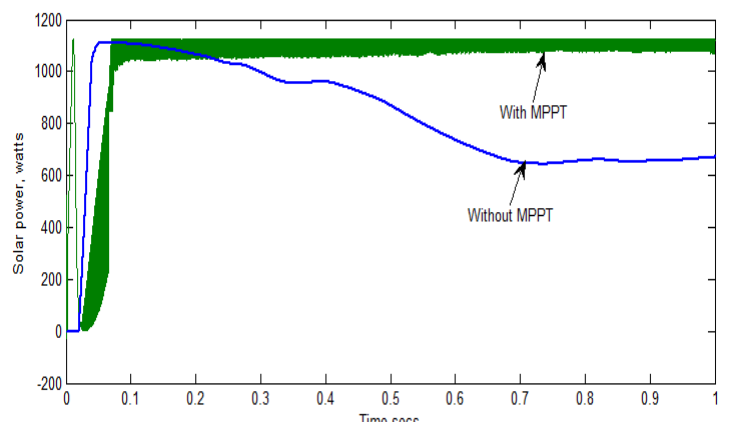

(b)

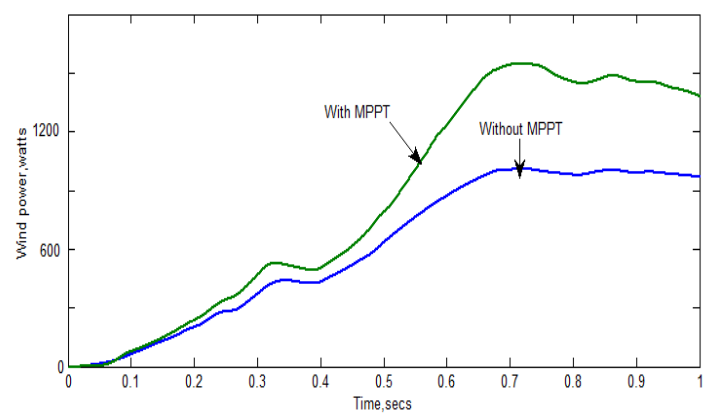

(c)

Figure 6. Comparison of solar and wind power, (b) with and (c) without MPPT

Figure 6(a). Flow chart for P \&O algorithm

\subsection{Design of cuk-sepic interface topology}

The interface is operated in continuous conduction mode of operation, the average voltage of the converter can be calculated as,

$$
\frac{V_{0}}{V_{I}}=\frac{-D}{1-D}
$$


the inductor and capacitor values can be calculated as follows

$$
\begin{aligned}
& \Delta I_{L 1}=\frac{V_{I^{*} D}}{L_{1} f} \\
& \Delta I_{L 2}=\frac{V_{I^{* D}}}{L_{2} f} \\
& \Delta I_{L 3}=\frac{V_{I^{* D}}}{L_{3} f} \\
& \Delta V_{C 1}=\frac{I_{I^{*}(1-D)}}{C_{1} f} \\
& \Delta V_{C 2}=\frac{I_{I^{*}(1-D)}}{C_{2} f} \\
& \Delta V_{C 1}=\frac{\Delta I_{L 2}}{8 C_{3} f}
\end{aligned}
$$

Where,

D : Duty cycle

$\mathrm{V}_{\mathrm{o}}$ : Output voltage

$\mathrm{V}_{\mathrm{i}}$ : Input voltage

f : Switching frequency of the switch $=20 \mathrm{kHz}$

The topology of cuk-sepic interface topology without and with MPPT is shown in Figure 7a and 7b respectively. It is also the combination of cuk and sepic converters. In order to reduce component and increase efficiency, components of cuk and sepic converters are arranged in such a way that the common elements are shared between themselves.

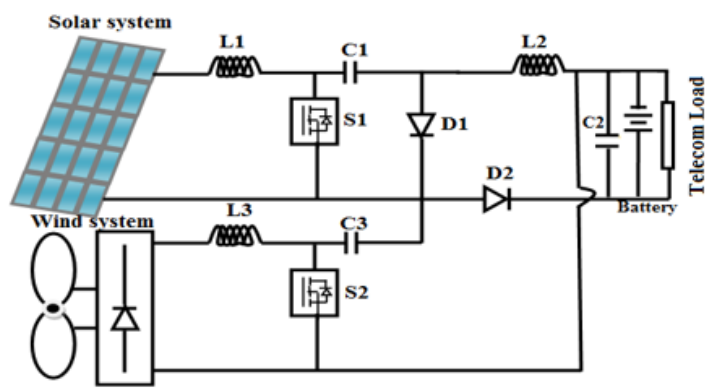

(a)

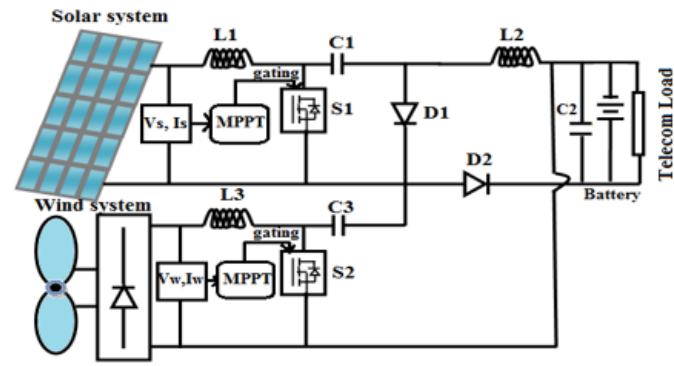

(b)

Figure 7. Cuk-sepic interface without (a) MPPT, (c) with MPPT

In Figure 7(a) and 7(b), cuk converter is used to process power from solar panel, sepic converter is used to process the power from wind system, both the outputs are connected to a common dc link which is used to power the load, therefore it is suitable for systems with low voltage rating like telecom. It allows both simultaneous and individual operation of solar and wind sources. Both the circuits are simulated with the parameters, $\mathrm{L}_{1}$ of $158 \mu \mathrm{H}, \mathrm{L}_{2}$ of $84.16 \mu \mathrm{H}, \mathrm{L}_{3}$ of $108.6 \mu \mathrm{H}, \mathrm{C}_{1}$ of $2906 \mu \mathrm{F}, \mathrm{C}_{2}$ of $1132 \mu \mathrm{F}$ and $\mathrm{C}_{3}$ of $1200 \mu \mathrm{F}$ resistive load of $1.92 \Omega$ and the switching frequency of $20 \mathrm{kHz}$ for its investigation. It is desired to obtain $48 \mathrm{~V}$ and $23 \mathrm{~A}$ from an inputs of $80 \mathrm{~V}$ and $50 \mathrm{~V}$. Battery power can be used as backup power which can compensate load demand when needed. The input and output voltage relationship of the cuk-sepic interface topology is derived by applying volt-second balance on inductors $\mathrm{L}_{1}, \mathrm{~L}_{2}$ and $\mathrm{L}_{3}$. Inductor $\mathrm{L}_{1}$ gives,

$$
\mathrm{d}_{1} * \mathrm{~V}_{1}+\left(1-\mathrm{d}_{1}\right) *\left(\mathrm{~V}_{1}-\mathrm{V}_{\mathrm{C}_{1}}\right)=0
$$

On inductor $\mathrm{L}_{3}$, 
$\mathrm{d}_{2} * \mathrm{~V}_{2}+\left(1-\mathrm{d}_{2}\right) *\left(\mathrm{~V}_{2}-\mathrm{V}_{\mathrm{C}_{3}}-\mathrm{V}_{\mathrm{C}_{2}}\right)=0$

On inductor $\mathrm{L}_{2}$,

$$
\mathrm{d}_{1} *\left(\mathrm{~V}_{\mathrm{c}_{1}}+\mathrm{V}_{\mathrm{c}_{3}}\right)+\left(\left(1-\mathrm{d}_{2}\right) *\left(-\mathrm{V}_{0}\right)\right)+\left(\left(\mathrm{d}_{2}-\mathrm{d}_{1}\right) *\left(\mathrm{~V}_{\mathrm{C}_{3}}\right)\right)=0
$$

By rearranging the equations (14), (15) and (16), the output voltage expression is obtained

$$
\mathrm{V}_{\mathrm{o}}=\mathrm{V}_{\mathrm{C}_{2}}=\left(\left(\frac{\mathrm{d}_{1}}{\left(1-\mathrm{d}_{1}\right)}\right) * \mathrm{~V}_{1}\right)+\left(\left(\frac{\mathrm{d}_{2}}{\left(1-\mathrm{d}_{2}\right)}\right) * \mathrm{~V}_{2}\right)
$$

Where,

$\mathrm{V}_{1}=\mathrm{Vs}_{\mathrm{s}}=$ Solar voltage

$\mathrm{V}_{2}=\mathrm{V}_{\mathrm{w}}=$ Wind voltage

$\mathrm{V}_{\mathrm{c} 1}, \mathrm{~V}_{\mathrm{c} 2}$ and $\mathrm{V}_{\mathrm{c} 3}=$ Voltage across Capacitors $\mathrm{C}_{1}, \mathrm{C}_{2}$ and $\mathrm{C}_{3}$

$\mathrm{d}_{1}=\mathrm{d}_{\mathrm{pv}}=$ duty cycle of switch $\mathrm{S}_{1}$

$\mathrm{d}_{2}=\mathrm{d}_{\mathrm{w}}=$ duty cycle of switch $\mathrm{S}_{2}$

\section{OPERATING MODES}

Depending on the conducting states of power switches S1 and S2, there are four different operating modes. They are (i) Mode-1 (S1 ON, S2 ON), (ii) Mode-2 (S1-ON, S2 OFF) (iii) Mode-3 ( S1-OFF, S2 ON) and (iv) Mode-4 (Both S1, S2-OFF). The voltage and current waveforms of cuk-sepic interface topology with MPPT is given in Figure 8.

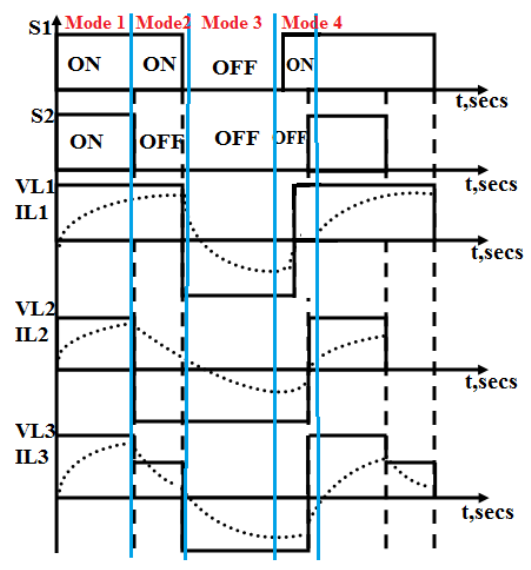

Figure 8. Voltage and current waveforms (with MPPT)

There are four different modes of operation of cuk-sepic interface with MPPT depending upon the conduction states of the switches $S_{1}$ and $S_{2}$. The working principle of different modes of the same are given below.

(i) Mode-1: Figure 9(a) shows the current direction of inductors $\left(\mathrm{I}_{\mathrm{L}}\right)$ when both switches $\mathrm{S}_{1}$ and $\mathrm{S}_{2}$ are conducting. The diodes $\mathrm{D}_{1}, \mathrm{D}_{2}$ are reverse biased. The power delivered from solar charges the inductor $\mathrm{L}_{1}$ and the wind power charges inductor $\mathrm{L}_{3}$. Energy stored in inductors $\mathrm{L}_{2}$, and $\mathrm{C}_{3}$ is transferred to $\mathrm{C}_{2}$, battery and load.

(ii) Mode-2: In this mode switch $\mathrm{S}_{1}$ conducts, switch $\mathrm{S}_{2}$ is in OFF position. The inductor current directions are shown in Figure $9(b)$. The diode $D_{1}$ is in reverse biased and $D_{2}$ is in forward biased. The power delivered from solar charges inductor $\mathrm{L}_{1}$, energy stored in inductors $\mathrm{L}_{2}$ is transferred to the capacitor $\mathrm{C}_{1}$ also charges $C_{2}$. Energy stored in $L_{3}$ is transferred to $C_{2}$ and $C_{3}$ which charges the battery and load.

(iii) Mode-3: In this mode swich $S_{1}$ is in OFF position and $S_{2}$ is in OFF position. The diodes $D_{1}$ is forward biased and $\mathrm{D}_{2}$ is reverse biased as shown in Figure 9(c). Energy stored in inductor $\mathrm{L}_{1}$ is transferred to 
capacitor $\mathrm{C}_{1}$. The wind source charges the inductor $\mathrm{L}_{3}$. The energy stored in $\mathrm{L}_{2}$ is transferred to the capacitor $\mathrm{C}_{2}$ which feeds the battery and the load.

(iv) Mode-4: Figure 9(d) shows the equivalent circuit for this mode. In this mode both the switches $S_{1}$ and $S_{2}$ are not conducting. So the diodes $D_{1}$ and $D_{2}$ are forward biased. Energy stored in inductor $L_{1}$ is transferred to capacitor $C_{1}$. Energy in stored in inductor $L_{2}$ and $L_{3}$ are transferred to $C_{2}$ and $C_{3}$ which feeds the load and charges the battery.

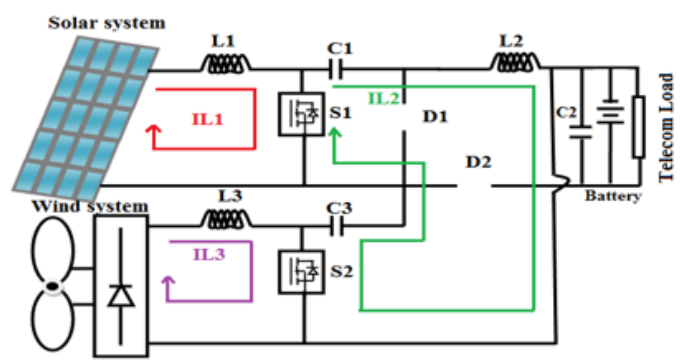

Figure 9(a). Mode-1 $\mathrm{S}_{1}, \mathrm{~S}_{2}-\mathrm{ON}$

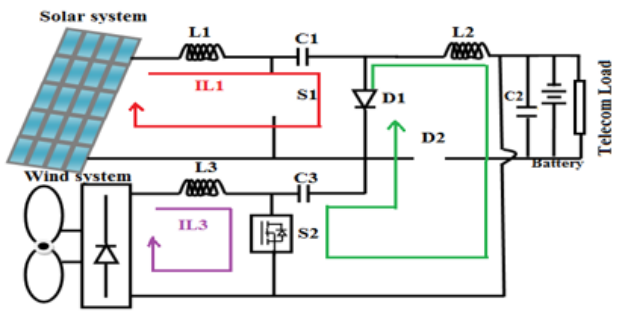

Figure 9(c). Mode-3 $\mathrm{S}_{1}$-OFF $\mathrm{S}_{2}-\mathrm{ON}$

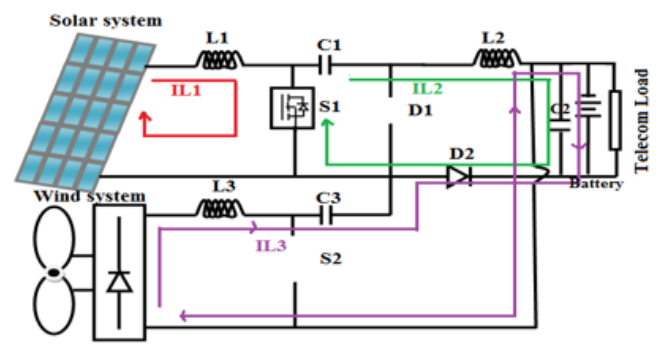

Figure 9(b). Mode-2 $\mathrm{S}_{1}-\mathrm{ON}, \mathrm{S}_{2}-\mathrm{OFF}$

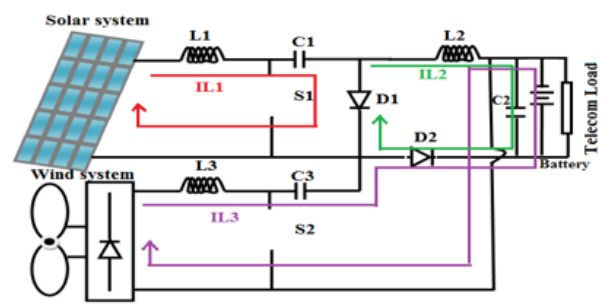

Figure 9(d). Mode- $4 \mathrm{~S}_{1}, \mathrm{~S}_{2}-\mathrm{OFF}$

\section{DISCUSSION ON SIMULATION RESULTS}

In order to predict the performance of the cuk-sepic interface topology a detailed MATLAB/SIMULINK based simulation is carried out on both with and without MPPT. The output voltage is regulated at $-48 \mathrm{~V}$ and current at $23 \mathrm{~A}$ in both the cases. Figure 10 shows the voltage and current through the loadin both the cases. It is observed that the voltage across both the topologies are measured as $-47.8 \mathrm{~V}$ and the current through both the topologies are measured as $-23 \mathrm{~A}$.
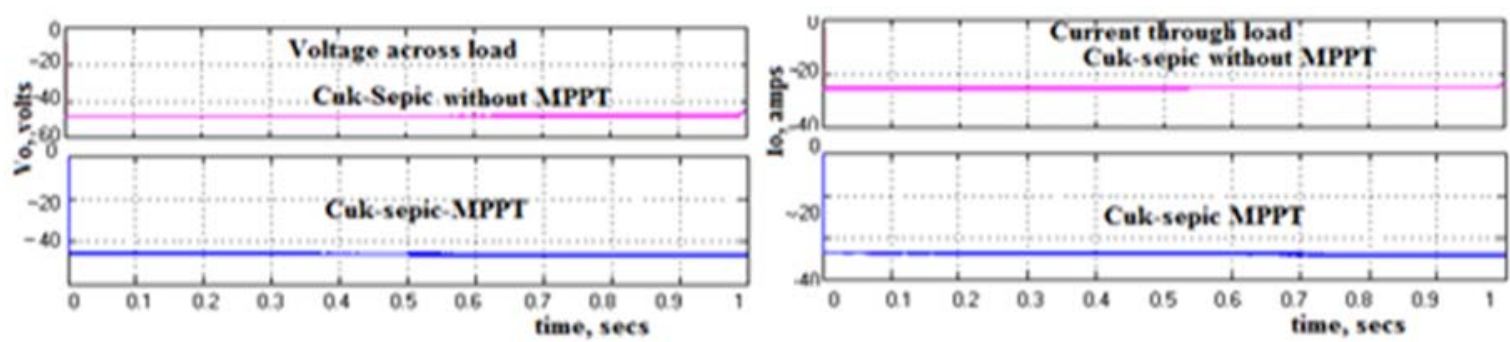

Figure 10. Voltage across and current through the load

Solar, wind power with MPPT and without MPPT are shown in Figure 11(a) and 11(b). Figure 11(a) exhibits that the topology with MPPT is having increased solar power. From Figure 11(b), it is clear that the topology with MPPT has increased wind power.

Int J Pow Elec \& Dri Syst, Vol. 10, No. 2, June 2019 : 917-927 


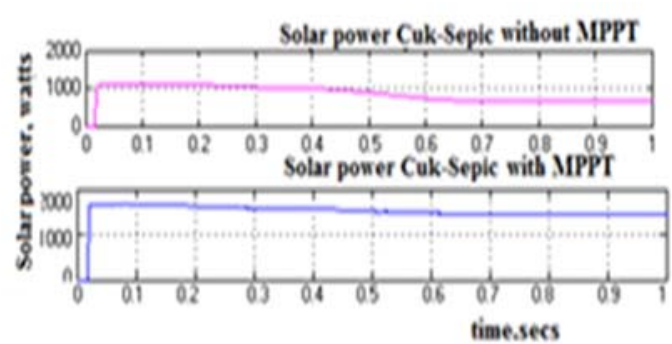

Figure 11(a). Solar power with and without MPPT

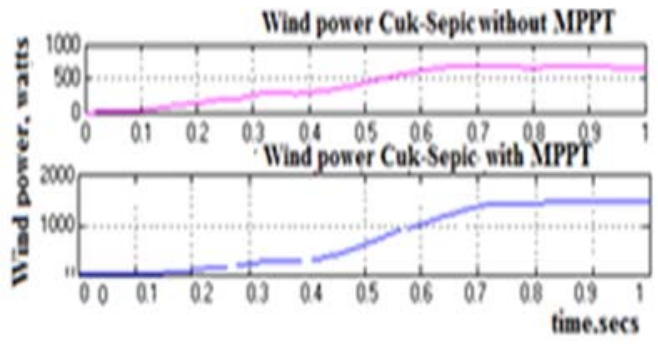

Figure 11(b). Wind power with and without MPPT

Under the conditions of same source inputs, load power and the designed values of energy storage elements, the componentwise losses are calculated for cuk-sepic topology with and without MPPT. Table 1 shows the comparison of efficiency of both the cases. Efficiencies of the cuk-sepic interface without and with MPPT are found to be $89 \%$ and $93 \%$. Thus it can be concluded that cuk-sepic interface with MPPT is more efficient.

\section{HARDWARE IMPLEMENTATION AND DISCUSSION}

Hardware implementation of the cuk-sepic interface topology with MPPT is done with the two sources each of $12 \mathrm{~V}$. It consists of power supply circuit, gate pulse generation circuit and cuk- sepic interface topology. They are explained in brief below. The design of cuk-sepic interface is given below: 12 Volt DC power supply, 2 Amps (Source 1), 12 Volt DC power supply, 5 Amps (Source 2), Optocoupler circuit with 15 Volt power supply, PIC18F2550 with 5 Volt power supply, Inductor L1-2mH, Inductor L2-3mH, Inductor L3 - 2mH, Capacitor C1-2200 $\mu \mathrm{F}, 100$ Volt, Capacitor C2-1200 $\mu \mathrm{F}, 100$ Volt, MOSFET-IRF840.

Figure $12 \mathrm{a}$ and $12 \mathrm{~b}$ Shows the design of cuk-sepic interface and gate pulse generation circuit in which the Mosfet switch is triggered by the pulses generated by the PIC controller. The pulses are made to trigger the switch through the optocoupler circuit. The hardware results of the cuk-sepic interface recorded in DSO are given here. Figure 13 shows the output voltage of $12 \mathrm{~V}$ for an input of source voltage $12 \mathrm{~V}, 2 \mathrm{~A}$ and $12 \mathrm{~V}, 5 \mathrm{~A}$.

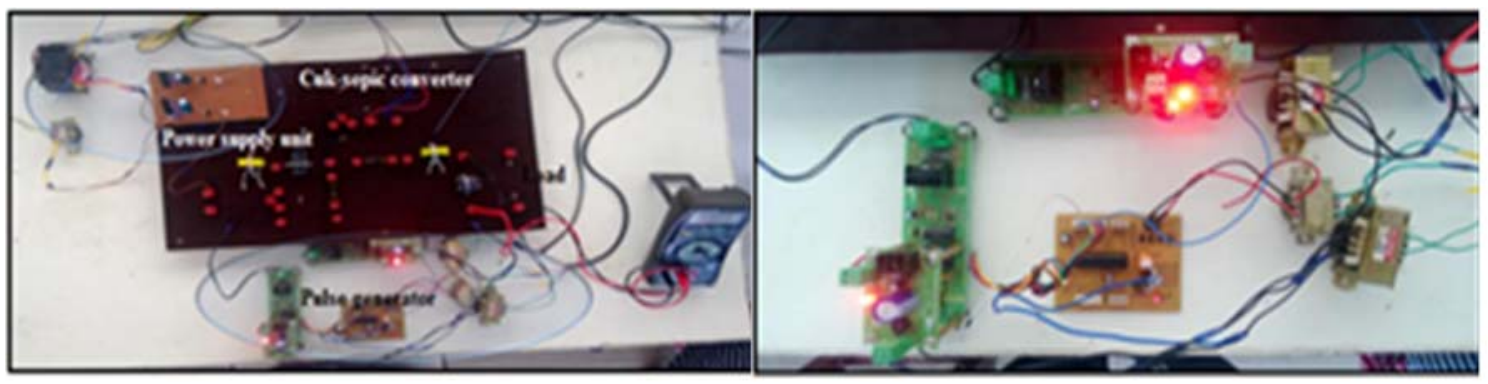

Figure 12(a). Design of cuk-sepic interface

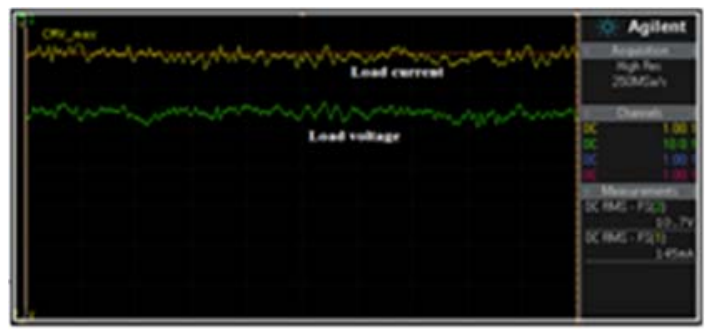

Figure 13(a). Load voltage and current
Figure 12(b). Gate pulse generation circuit
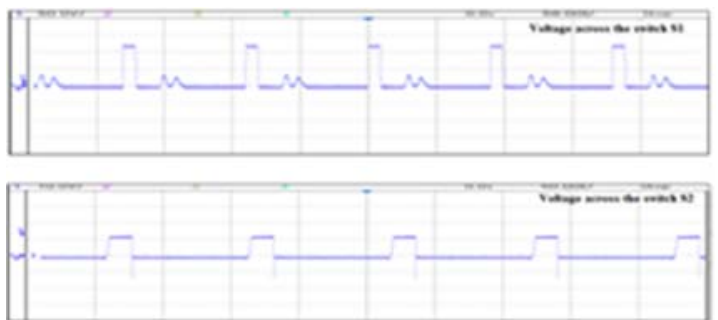

Figure 13(b). Voltage across the switches 
Table 1 Efficiency comparison of renewable energy interface

\begin{tabular}{|c|c|c|c|}
\hline Component & Parameter & Cuk-sepic with MPPT & Cuk-sepic without MPPT \\
\hline \multirow{5}{*}{ Inductor $\mathrm{L}_{1}$} & Average Current & 22.45 & 28.23 \\
\hline & Current Ripple & $13.36 \%$ & $42.51 \%$ \\
\hline & $\Delta I_{L}$ & 3 & 12 \\
\hline & Energy storage & 0.04 & 0.06 \\
\hline & Copper Losses & 6.05 & 9.56 \\
\hline \multirow{5}{*}{ Inductor $\mathrm{L}_{2}$} & Average Current & 22.19 & 12.13 \\
\hline & Current Ripple & $45.07 \%$ & $82.44 \%$ \\
\hline & $\Delta I_{L}$ & 10 & 10 \\
\hline & Energy storage & 0.02 & 0.01 \\
\hline & Copper Losses & 5.91 & 1.77 \\
\hline \multirow{5}{*}{ Inductor $\mathrm{L}_{3}$} & Average Current & 22.66 & 1.95 \\
\hline & Current Ripple & $22.07 \%$ & $41.03 \%$ \\
\hline & $\Delta I_{L}$ & 5 & 0.8 \\
\hline & Energy storage & 0.05 & 0.00 \\
\hline & Copper Losses & 0.16 & 0.05 \\
\hline \multirow{7}{*}{ CapacitorC $_{1}$} & Voltage(Vc1) & 52 & 46.7 \\
\hline & Average Voltage & 51.9 & 46.6 \\
\hline & Voltage Ripple & $0.39 \%$ & $0.32 \%$ \\
\hline & $\Delta V_{C 1}$ & 0.2 & 0.15 \\
\hline & Copper Losses & 22.32 & 26.06 \\
\hline & Energy storage & 3.91 & 3.15 \\
\hline & Voltage(Vc2) & 48.2 & 46.8 \\
\hline \multirow{5}{*}{ CapacitorC $_{2}$} & Average Voltage & 48 & 46.45 \\
\hline & Voltage Ripple & $0.083 \%$ & $0.11 \%$ \\
\hline & $\Delta V_{C 2}$ & 0.4 & 0.05 \\
\hline & Copper Losses & 17.65 & K225.89 \\
\hline & Energy storage & 1.32 & 1.24 \\
\hline \multirow{7}{*}{ CapacitorC $_{3}$} & Voltage(Vc3) & 7 & 4.5 \\
\hline & Average Voltage & 6.75 & 4 \\
\hline & Voltage Ripple & $7.41 \%$ & $25.00 \%$ \\
\hline & $\Delta V_{C 3}$ & 0.5 & 1 \\
\hline & Copper Losses & 0.55 & 0.19 \\
\hline & Energy storage & 0.01 & 0.00 \\
\hline & Peak current & 32.04 & 4.6 \\
\hline \multirow{3}{*}{ Switch $S_{1}$} & Switch voltage & 53 & 48 \\
\hline & Conduction losses & 1.3 & 10.2 \\
\hline & switching losses & 2.8 & 10.8 \\
\hline \multirow{5}{*}{ Switch $S_{2}$} & Peak current & 32.38 & 26.95 \\
\hline & Switch voltage & 58 & 52 \\
\hline & Conduction losses & 1.9 & 7.3 \\
\hline & switching losses & 1.3 & 4.3 \\
\hline & Peak current & 31.94 & 7.7 \\
\hline \multirow{3}{*}{ Diode $\mathrm{D}_{1}$} & Diode voltage & 48 & 46 \\
\hline & Conduction losses & 10.2 & 10.6 \\
\hline & switching losses & 2.8 & 3.1 \\
\hline \multirow{6}{*}{ Diode $\mathrm{D}_{2}$} & Peak current & 32.19 & 13.7 \\
\hline & Diode voltage & 51 & 48 \\
\hline & Conduction losses & 1.4 & 1.9 \\
\hline & switching losses & 1.9 & 2.2 \\
\hline & Total Losses & 84.93 & 154.48 \\
\hline & Efficiency & $93 \%$ & $89 \%$ \\
\hline
\end{tabular}

\section{CONCLUSION}

A hybrid wind and solar energy system with single cuk-sepic converter topology is used. This topology allows the two sources to supply the load separately or simultaneously depending on the availability of the energy sources. The output voltage obtained from the hybrid system is the sum of the inputs of the cuk-sepic converters. This system uses less number of components and improved efficiency. This paper also presents the comparison of efficiencies of cuk-sepic interface topology with and without MPPTcontroller. The use of MPPT controller further improves the efficiency than the basic one without MPPT controller. From the analysis it has been found that the efficiency of cuk-sepic interface topology with MPPT has higher efficiency and lesser losses. Solar and wind power are also plotted. Switching losses and conduction losses of cuk-sepic with MPPT is comparatively reduced. So, cuk-sepic converter with MPPT is found to be very attractive in terms of efficiency, component size, and ripples.

Int J Pow Elec \& Dri Syst, Vol. 10, No. 2, June 2019 : 917-927 


\section{REFERENCES}

[1] Yousef Mahmoud, W.Xiao and H.H.Zeineldin. "A Simple Approach to Modeling and Simulation of Photovoltaic Modules", IEEE Transactions on Sustainable Energy, vol. 3 [1], pp 185-186, 2012.

[2] Pradhan. S.K and Das.D. "Modeling and simulation of PV array with boost converter: An open loop study". National Institute of Technology, 2011.

[3] Nath. S and Rana.S. "The modeling and simulation of wind energy based power system using MATLAB". International Journal of Power System Operation and Energy Management, vol. 1, pp 12-19, 2011.

[4] Bharanikumar. R, Nirmal Kumar.A, "Analysis of wind turbine driven PM generator with power converters". International Journal of Computer and Electrical Engineering, Vol. 2, no. 4, pp 766-769, 2010.

[5] Ersan Kabalci. "Design and analysis of a hybrid renewable energy plant with solar and wind power". Energy Conversion and Management, vol. 72, pp. 51-59, 2013.

[6] Xiong Liu., Poh Chiang Loh., Peng Wang and Frede Blaabjerg. "A direct power conversion topology for grid integration of hybrid AC/DC energy resources". IEEE Transactions on Industrial Electronics, vol. 60, no. 12, pp. 5696-5707, 2013.

[7] Salameh. Z.M and Giraudand. F. "Steady-state performance of a grid-connected rooftop hybrid wind-photovoltaic power system with battery storage". IEEE transactions on energy conversion, vol. 16 [1], pp 1-9, 2001.

[8] Billinton.R and Karki.R. "Capacity expansion of small isolated power systems using PV and wind Energy". IEEE Transactions on Power Systems, vol. 16, pp 892-897, 2001.

[9] Neng Zhang., Danny Sutanto., Kashem.M and Muttaqi. "A review of topologies of three-port dc-dc converters for the integration of renewable energy and energy storage system". Renewable and Sustainable Energy Reviews. Vol. 56, pp. 388-401, 2016.

[10] Akar, Furkan and Enus Ugur. "A bidirectional non-isolated multi input dc-dc converter for hybrid energy storage systems in electric vehicles". IEEE Transactions on Vehicular Technology. Vol. 65, no. 10, pp. 7944-7955, 2016.

[11] Shagar Banu.M., Vinod.S and Lakshmi. S. "Design of dc-dc converter for hybrid wind solar energy system". International Conference on Computing, pp. 429-435, 2012.

[12] Narendranath. K.V., Viswanath.Y, Suresh Babu.K., Arunkumar.G and Elangovan.D. "Solar fed dc-dc single ended primary inductance converter for low power application”. Materials Science and Engineering. Vol. 263, pp 1-7, 2017.

[13] Niranjana Siddharthan, Baskaran Balasubramanian. "Performance Evaluation of SEPIC, Luo and ZETA converter". International Journal of Power Electronics and Drives Systems (IJPEDS), Vol.10, No.1, pp. 374-380, 2018.

[14] Ibrahim Alhamrouni, M. K. Rahmat, F. A. Ismail, Mohamed Salem, Awang Jusoh, T. Sutikno. "Design and Development of SEPIC DC-DC Boost Converter for Photovoltaic Application". International Journal of Power Electronics and Drives Systems, Vol.10, No.1, 406-413, 2018.

[15] Lorentz.V. "Bidirectional dc voltage conversion for low power applications", IEEE transactions on power electronics, vol. 15, no. 4, pp 595-606, 2000.

[16] Jafar Marjani., Amir Imani., Arsalan Hekmati.E and Afjei. "A new dual output dc-dc converter based on SEPIC and cuk converters". International Symposium on Power Electronics, Electrical Drives, Automation and Motion (SPEEDAM), pp 946-950, 2016.

[17] Suresh.K.V, Vinayaka.K.U, Rajesh.U. "A cuk-sepic fused converter topology for wind-solar hybrid systems for stand-alone systems". IEEE Power, Communication and Information Technology Conference (PCITC), pp 1-6, 2015.

[18] Maria Bella Ferrera., Salvador, Litran, Eladio Duran Aranda and Jose Manuel Andujar Marquez. "A Converter for bipolar dc link based on SEPIC-Cuk combination". IEEE Transactions on Power Electronics, vol. 30, no. 12, pp. 6483-6487, 2015.

[19] Sajib Chakraborty., Salim Reza. S.M and Wahidul Hasan. "Design and analysis of hybrid solar-wind energy system using CUK \& SEPIC converters for grid connected inverter application". IEEE 11th International Conference on Power Electronics and Drive Systems (PEDS), pp278-283, 2015.

[20] Jayalakshmi.N. S., Gaonkar.D.N Pramod Bhat Nempu. "Power Control of PV/Fuel Cell/Supercapacitor hybrid system for stand-alone applications". International Journal of Renewable Energy Research (IJRER), Vol.6, Issue. 2, pp. 672-679, 2016.

[21] Murugesan, Karthik and Vijayachitra Senniappan. "Dynamic modeling and analysis of power sharing control strategy based fuel cell/battery assisted hybrid electric vehicle system". International Journal of Renewable Energy Research (IJRER), Vol. 5, no. 1, pp. 139-150, 2015.

[22] Saravanan. S and Ramesh Babu. N. "Maximum power point tracking algorithms for photovoltaic system-A review”. Renewable and Sustainable Energy Reviews, vol. 57, pp. 192-204, 2016. 